\title{
Cytological Investigations in Three Species of Oplismenus P. Beauv. (Gramineae)
}

\author{
J. D. Chaudhary \\ Lecturer in Botany, D. A. V. College for Men, Chandigarh-10, India
}

Received April 2, 1981

Oplismenus is a small genus of the family Gramineae, represented by 15 tropical species (cf. Airy-Shaw 1973). Bor (1960) described 4 species of this genus from Indian sub-continent. Present communication deals with the cytology of three species of the genus. These are $O$. burmannii, $O$. compositus and $O$. undulatifolius. Possible role of hybridization in the origin of new taxa in the genus has been discussed.

\section{Materials and methods}

Material for all the three species was collected from natural populations of North-Eastern India. Meiosis was studied in pollen mother cells, for which purpose young unopened inflorescences were fixed in 1:3 acetic alcohol and stored in $70 \%$ alcohol until use. Anthers were squashed in $20 \%$ acetocarmine and desired slides were made permanent in Butanol-acetic acid grades. All photomicrographs are given at a uniform magnification of $\times 1500$. Voucher specimens have been deposited in the herbarium of the Botany Department, Panjab University, Chandigrah, India.

\section{Results}

Table 1 summarizes present chromosome counts and previous records in the presently worked out species. Some of the interesting cytological features in these are given below.

\section{O. burmannii (Retz.) P. Beauv.}

A very common annual species of hills and plains of N.E. India. This species often forms pure mates under the shades of trees and in open spaces. Blooms during August-October.

Three cytological races a diploid with $n=9$, a tetraploid with $n=18$ and a pentaploid with $2 n=45$ were detected from present area under survey. Interestingly diploids were collected from lower altitudes only, ascending in hills up to $400 \mathrm{~m}$. Tetraploids were found both in hills and plains. Pentaploid taxon was collected from a limited area in Shillong $(1500 \mathrm{~m})$ which shows its recent origin. Restriction of diploids to the lower altitudes is probably related to temperature conditions. 
Meiosis was normal with complete bivalent formation in the diploid $(n=9)$ and tetraploid $(n=18)$. In pentaploid from with $2 n=45$, meiosis was quite erratic,

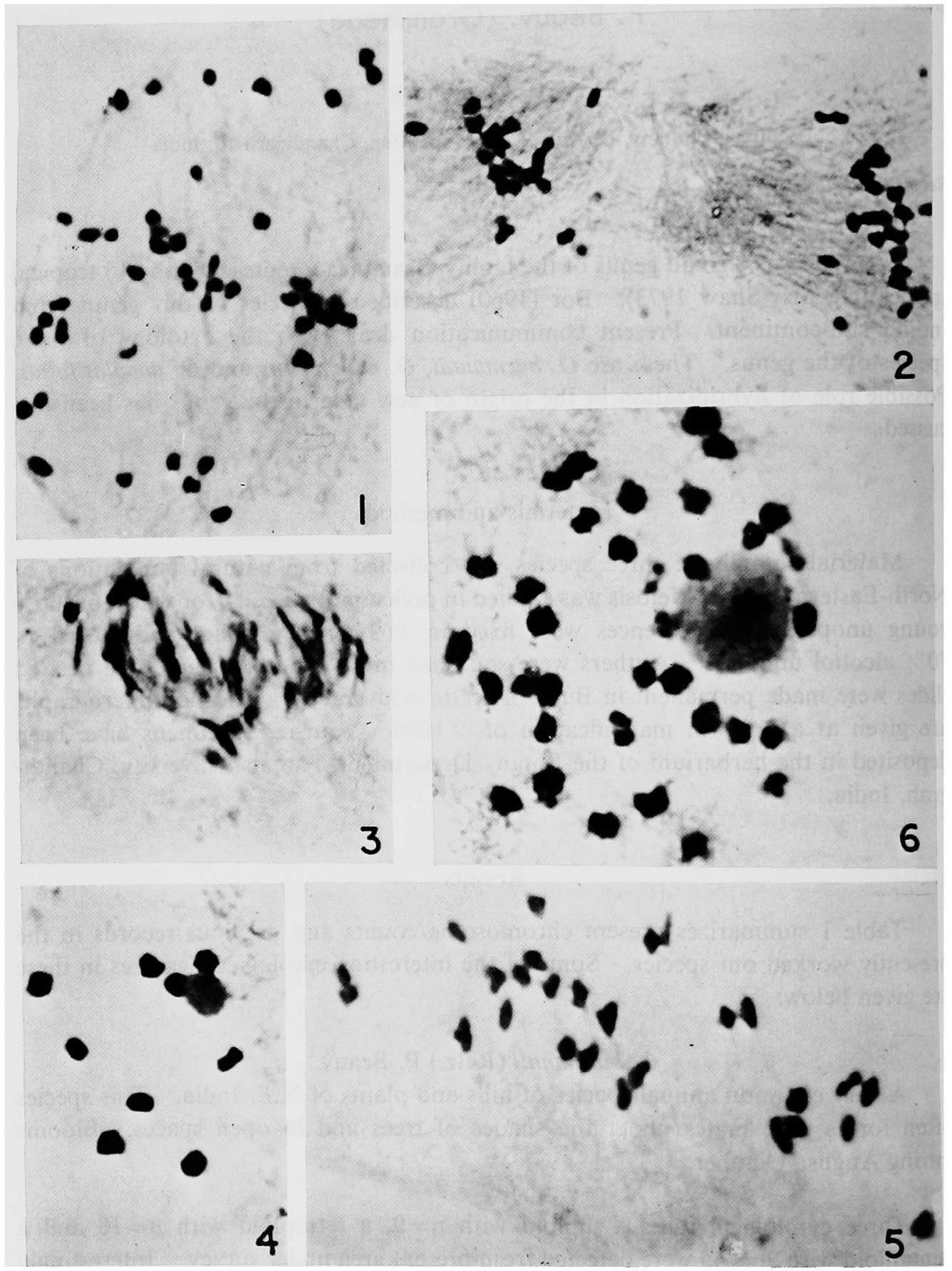

Figs. 1-6. 1-3: Oplismenus burmannii $(2 \mathrm{n}=45) . \quad 1, \mathrm{M}_{\mathrm{I}}$ showing some of the univalents at equator and others free on the spindle. 2, two daughter cells showing 20 and 25 chromosomes each. 3, bridges at $\mathrm{A}_{\mathrm{II}}$ indicating break down of meiosis. 4-6; $O$. compositus. 4, diakinesis in diploid showing 9 bivalents and a nucleolus. 5, $\mathrm{M}_{\mathrm{I}}$ in hexaploid showing 27 bivalent. 6, diakinesis in octoploid showing 36 bivalents and a nucleolus. 
as expected. It was found to be a purely asynaptic taxon. At MI (Fig. 1) some of the univalents congressed at equator while other did not and were distributed to the poles at random, resulting unequal distribution of chromosomes. Fig. 2 shows two daughter cells with 20 and 25 chromosomes in each. Second division was also erratic as univalent bridges were seen in high percentage of cells (Fig. 3). As a result there were complete break down of meiosis. In addition to PMC's with 45 chromosomes a small number of multinucleate pollen mother cells could be observed. Pollen stainability was nil, which is the obvious reason of no seed setting in this taxon. This taxon propagates by vegetative mean only. A morphological comparison of the three taxa is given in Table 2 (see also Fig. 7). Small sized diploids can be easily distinguished in the field.

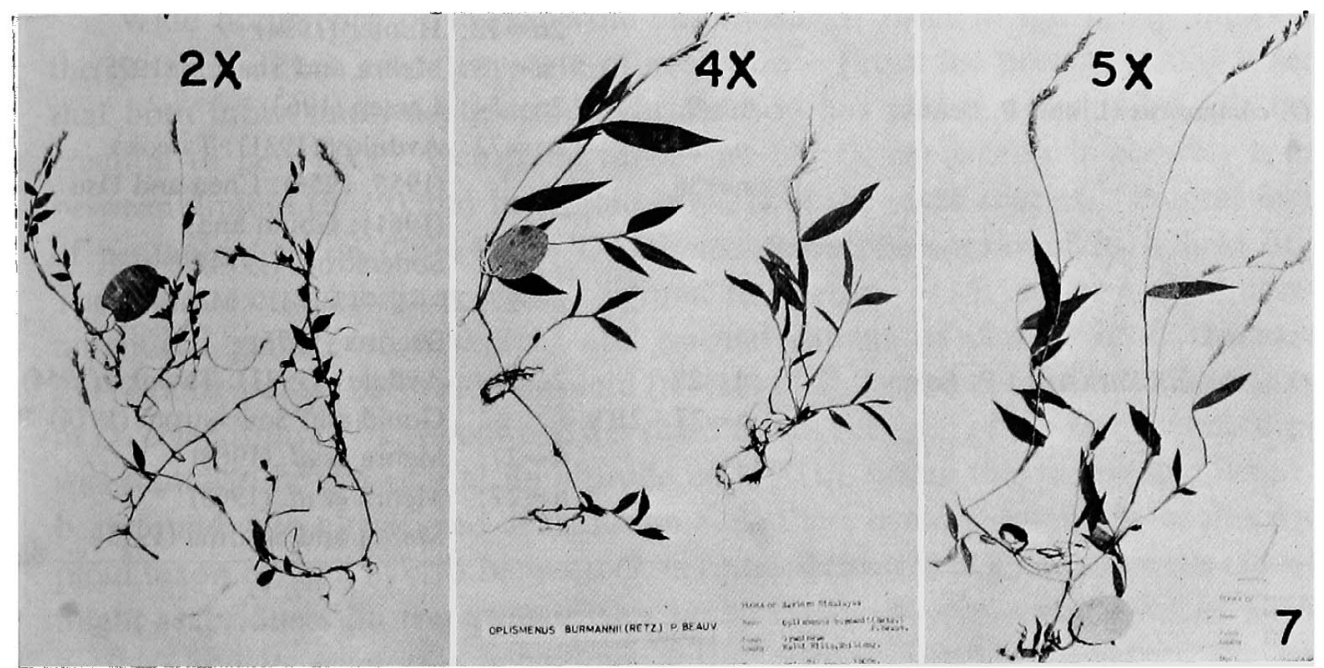

Fig. 7. Oplismenus burmannii. Cytotypes with $\mathrm{n}=9, \mathrm{n}=18$ and $2 \mathrm{n}=45$.

Of the three chromosome numbers $n=9,18$ and $2 n=45$ presently encounted, $\mathrm{n}=9$ and $\mathrm{n}=18$ are already on record (see Table 1). Chromosome report of $2 \mathrm{n}=44$ by present author (Mehra and Chaudhary 1975) is also for the presently reported pentaploid taxon, as further careful scrutiny of slides clearly shows 45 univalents at MI (Fig. 1).

\section{O. compositus (Linn.) P. Beauv.}

This annual species grows gregariously in the forests and glades in open shady places. The awns are sticky and responsible for dispersal of seeds. Blooms during August-October.

Three cytological forms $n=9$ (Fig. 4), $n=27$ (Fig. 5) and $n=36$ (Fig. 6) were discovered from present area under survey. Hexaploid form with $n=27$ was most common. Meiosis was normal in all the three forms. All the three taxa showed an anastomosing pattern of morphological traits and could not be distinguished from one another in the field.

Of the three chromosome counts $n=9,27$ and 36 presently reported $n=27$ 
and $n=36$ are already on record (see Table 1). Diploid taxon with $n=9$ is a new record for this species. It is interesting to mention that the diploid taxon was found to be rather rare in this area and may probably be on way to becoming extinct.

Table 1 .

\begin{tabular}{|c|c|c|}
\hline \multirow{2}{*}{ Species } & \multicolumn{2}{|r|}{ Chromosome number } \\
\hline & Present & Previous \\
\hline \multirow[t]{2}{*}{ Oplismenus burmannii (Rets.) P. Beauv. } & $\begin{array}{l}n=9 \\
n=18\end{array}$ & $\begin{array}{l}2 \mathrm{n}=18: \text { Sharma and Jhuri (1959); } \\
\text { Larsen (1959) }\end{array}$ \\
\hline & $2 n=45$ & $\begin{aligned} 2 n=36: & \text { Pohl and Davidse }(1971) \\
& \text { Reeder }(1971) \\
2 n=44: & \text { Mehra and Chaudhary }(1975) ; \\
2 n=72: & \text { Hunter (1934) } \\
n=18: & \text { Mehra and Sharma }(1975)\end{aligned}$ \\
\hline \multirow[t]{3}{*}{ O. compositus (Linn.) P. Beauv. } & $n=9$ & $2 n=54:$ Larsen $(1963)$ \\
\hline & $\begin{array}{l}n=27 \\
n=36\end{array}$ & $\begin{aligned} 2 \mathrm{n}=72: & \text { Avdulov (1931); Tateoka } \\
& (1955,1956) ; \text { Chen and Hsu } \\
& (1961) ; \text { Gould and } \\
& \text { Soderstrom (1974) }\end{aligned}$ \\
\hline & & $\begin{array}{c}\mathrm{n}=27,27+1-13 \text { B's: Mehra and } \\
\text { Sharma }(1975)\end{array}$ \\
\hline O. undulatifolius (Ard.) P. Beauv. & $\begin{array}{l}\mathrm{n}=27 \\
\mathrm{n}=27+2 \mathrm{~B} ' \mathrm{~s}\end{array}$ & $\begin{array}{ll}2 \mathrm{n}=54: & \text { Avdulov (1931); Tateoka (1954) } \\
& \text { Gould and Soderstrom (1974) } \\
\mathrm{n}=27: & \text { Mehra } \text { et al. } \text { (1968) } \\
\mathrm{n}=27: & \text { Mehra et al. }(1968) \\
& \text { Mehra and Sharma (1975) }\end{array}$ \\
\hline
\end{tabular}

Table 2.

\begin{tabular}{|c|c|c|c|}
\hline Characters & $\begin{array}{c}\text { Diploid } \\
(\mathrm{n}=9)\end{array}$ & $\begin{array}{l}\text { Tetraploid } \\
(n=18)\end{array}$ & $\begin{array}{l}\text { Pentaploid } \\
(2 n=45)\end{array}$ \\
\hline Habit & $\begin{array}{l}\text { Annual growing at } \\
\text { low altitudes } \\
\text { (upto } 400 \mathrm{~m} \text { ) }\end{array}$ & $\begin{array}{l}\text { Annual growing at } \\
\text { altitudes in the } \\
\text { area }\end{array}$ & $\begin{array}{l}\text { Perennial found at } \\
\text { altitude of } 1500 \mathrm{~m}\end{array}$ \\
\hline Plant height & $5-15 \mathrm{~cm}$ & $20-40 \mathrm{~cm}$ & $30-45 \mathrm{~cm}$ \\
\hline Length of second internode & $1.0-2.5 \mathrm{~cm}$ & $1.5-3.5 \mathrm{~cm}$ & $2.7-4.0 \mathrm{~cm}$ \\
\hline \multicolumn{4}{|l|}{ Leaf: } \\
\hline Lamina length & $0.7-1.9 \mathrm{~cm}$ & $2.1-7.0 \mathrm{~cm}$ & $2.5-7.5 \mathrm{~cm}$ \\
\hline Lamina breadth & $0.25-0.70 \mathrm{~cm}$ & $0.5-1.4 \mathrm{~cm}$ & $0.5-1.4 \mathrm{~cm}$ \\
\hline Sheath length & $0.4-1.8 \mathrm{~cm}$ & $0.9-3.4 \mathrm{~cm}$ & $0.9-3.5 \mathrm{~cm}$ \\
\hline Inflorescence length & $2-3 \mathrm{~cm}$ & $3.0-7.5 \mathrm{~cm}$ & $5.0-7.5 \mathrm{~cm}$ \\
\hline Spikelet size & $2.5 \mathrm{~mm}$ & $2.5 \mathrm{~mm}$ & $2.9 \mathrm{~mm}$ \\
\hline Awn & smooth & smooth & slightly scabrid \\
\hline \multicolumn{4}{|l|}{ Pollen: } \\
\hline Size & $24 \pm 2 \mu$ & $30 \pm 2 \mu$ & $30 \pm 2 \mu$ \\
\hline
\end{tabular}

O. undulatiofolius (Ard.) P. Beauv.

It is a hill grass met with at altitudes above $1,400 \mathrm{~m}$. It was found growing very commonly in Shillong area, but was rather uncommon is other parts of Khasi, Jaintia and Garo hills. Blooms during August-October. 
In this area this species was found to be at hexaploid level with $n=27$. One collection No. J-507 possessed a pair of B-chromosomes in addition to the normal complement of 27 bivalents. These B-chromosomes were observed in $36 \%$ of PMC's. Meiosis was normal with complete bivalent formation.

\section{Discussion}

From the available cytological information and present studies it is obvious that main basic chromosome number in the genus is $x=9$. However there are other reports like $2 \mathrm{n}=20$ in $O$. najada (Parodi 1946, Nunez 1952), $2 \mathrm{n}=60$ in $O$. hirtellus (de Wet 1958) and $2 \mathrm{n}=90$ in O. hirtellus (Pohl and Davidse 1971). These reports suggests that $\mathrm{x}=10$ is another basic number in the genus.

Wide occurrence of intraspecific chromosomal races in the genus shows that the genus is still in an active state of evolution. From the present results it seems that both intra- and inter-specific hybridization has played a very vital role in the creation of new taxa. Octoploid taxon $(\mathrm{n}=36)$ O. compositus is possibly a cross between diploid $(n=9)$ and hexaploid $(n=27)$ of the same species. Present finding of pentaploid taxon $(2 \mathrm{n}=45)$ in $O$. burmannii also be speaks of its hybrid origin. There are two possibilities of the origin of this taxon. 1) It can be a cross between unreduced gamete of tetraploid and normal gamete of diploid of $O$. burmannii. 2) It can be a cross between tetraploid $(\mathrm{n}=18)$ of $O$. burmannii and hexaploid $(\mathrm{n}=27)$ of $O$. compositus. First possibility is ruled out in the light of the fact that no diploid was found to be growing at an altitude of $1500 \mathrm{~m}$, where this pentaploid taxon has been found with a restricted distribution. So there is more possibility of this pentaploid taxon being a hybrid between $O$. burmannii $(\mathrm{n}=18)$ and $O$. compositus $(\mathrm{n}=27)$. Slight scabridness on the awns of this taxon (Scabrid awns a character of $O$. compositus) and its asynaptic behaviour during meiosis further strengthen the possibility of its being a hybrid between two species. As already mentioned that this taxon seems to have a very recent origin, so it can not be assigned the rank of a new species unless it is fixed in nature and does not go extinct after few generations. Presently this hybrid has been kept in $O$. burmannii as it resembles more to this species.

\section{Summary}

Cytological studies were made in Oplismenus burmannii $(\mathrm{n}=9,8$ and $2 \mathrm{n}=45)$, $O$. compositus $(\mathrm{n}=9,27,36)$ and $O$. undulatifolius $(\mathrm{n}=27,27+2$ B's). Pentaploid taxon $(2 \mathrm{n}=45)$ in $O$. burmannii and diploid taxon $(\mathrm{n}=9)$ in $O$. compositus are new records. Pentaploid of $O$. burmannii was found to be an asynaptic taxon and has been discussed as a hybrid between $O$. burmannii $(\mathrm{n}=18)$ and $O$. compositus $(\mathrm{n}=27)$.

\section{Acknowledgements}

Thanks are due to PL-480 authorities of U.S.A. for financial assistance provided under the project FG-In-482 (A7-CR.441). Thanks are also due to Prof. P. N. 
Mehra of Department of Botany, Panjab University Chandigarh of valuable suggestions.

\section{Literature cited}

Airy-Shaw, H. K. 1973. A Dictionary of Flowing Plants and Ferns (Revised 8th ed. of late J, C, Willis). Univ. Press Cambridge.

Avdulov, N.P. 1931. Karyo-systematische Untersuchungen der Familie Gramineen. Bull. Appl. Bot., Gent. Plant Breeding. Supp. 43: 1-438.

Bor, N. L. 1960. The Grasses of Burma, Ceylon, India and Pakistan. Pergamon Press (Revised edition 1973).

Chen, C. C. and Hsu, C. C. 1961. Cytological studies of Taiwan grasses I. Tribe Paniceae, Bot. Bull. Acad. Sin. 2: 101-110.

Gould, F. W. and Soderstrom, T. R. 1974. Chromosome numbers of some Ceylon grasses. Cand. Jour. Bot. 52: 1075-1090.

Hunter, A. W. S. 1934. A karyosystematic investigation in the Gramineae. Canad. Jour. Res. 11: 213-241.

Larsen, K. 1963. Studies in the flora of Thailand 14. Cytological studies in vascular plants of Thailand. Dansk. Bot. Ark. 20: 211-275.

Mehra, P. N. and Chaudhary, J. D. 1975. In IOPB chromosome number reports XLIX Taxon 23: 501-516.

- and Khosla, P. K., Kohli, B. K. and Koonar, J. S. 1968. Cytological studies in the North Indian grasses (Part 1). Res. Bull. Panjab. Univ. 19: 157-230.

- and Sharma, M, L. 1975. Cytological studies in some Central and Eastern Himalayan grasses. II. The Paniceae. Cytologia 40: 75-89.

Nünez, O. 1952. Investigaciones cariosistematicas en las Gramineas Argentinas de La tribus "Paniceae". Rev. Fac. Agron La Planta 28: 229-256.

Parodi, L. R. 1946. Gramineas Bonariensis Claue para La determinacion de Los generas Y enumeracion de Las especies. Buenos Aires Acame. Agency 1-112.

Pohl, R. W. and Davidse, G. 1971. Chromosome number of Cost Rican grasses. Brittonia 23: 293-324.

Reeder, J. R. 1971. Notes on Mexican grasses IX. Miscellaneous chromosome numbers. Brittonia 23: 105-117.

Sharma, A. K. and Jhuri, L. 1959. Chromosome analysis of grasses I. Genetica Iberica 11: 145-173.

Tateoka, T. 1954. Karyotaxonomic studies in Poaceae II. Ann. Rept. Natl. Inst. Genet. (Japan) 5: 68-69.

- 1955. Karyotaxonomic studies in Poaceae III. Ann. Rept. Natl. Inst. Genet. (Japan) 6: 73-74.

- 1956. Karyotaxonomy in Poaceae IV. Chromosome and systematic relationship of several species. Bot. Mag. (Tokyo) 69: 112-118.

de Wet, J. M. J. 1958. Additional chromosome numbers in Transvaal grasses. Cytologia 23: 113-118. 